\title{
LOBBYING BY FOREIGN GOVERNMENTS ON THE SUGAR ACT AMENDMENTS OF 1962
}

\author{
Daniel M. Berman* and Robert A. Heineman†
}

\section{INTRODUCTION}

During congressional consideration of what were to become the Sugar Act Amendments of 1962 , lobbying by representatives of foreign governments reached something of an all-time high in intensity. Events had conspired to create in a number of sugar-producing countries a passionate, if understandable, interest in the latest revision of a United States program that had been on the books since 1934.

The program had been brought into existence by the Jones-Costigan Act. ${ }^{1}$ This act was passed at least partly for the purpose of protecting domestic sugar producers by keeping the price of their commodity at an artificially high level. ${ }^{2}$ In an attempt to stabilize the price and supply of sugar, the act imposed a system of regulation upon the industry. One of the principal devices to be employed was an arrangement for the allocation of quotas to domestic and foreign suppliers on the basis of the Secretary of Agriculture's annual estimate of the nation's sugar needs. ${ }^{3}$

Under normal circumstances, the regulated supply assured by the quota system caused the domestic market price of sugar to be higher than the world market price. But to encourage the availability of a reliable supply of sugar from other countries, Congress permitted sugar interests in the foreign nations that held quotas to retain the premium resulting from the higher domestic price. Cuba was the main beneficiary of the quota system, both because it had become the chief foreign supplier of sugar and because it was the foreign source of sugar that was closest to the East and Gulf Coasts, where most United States refineries are located. It received not only the largest quota, but a preferential tariff rate as well.

The first extensive congressional revision of the program contained in the JonesCostigan Act took place in 1947. An administrative regulation, issued in 1936, had awarded several countries a preferred status in the event that it proved necessary to buy sugar from other than quota countries. ${ }^{4}$ The Sugar Act of 1948 gave statutory

- A.B. 1947, Rutgers University; A.M. 1948, University of Wisconsin; Ph.D. 1957, Rutgers University. Associate Professor of Government and Public Administration, The American University. Author, A Bilx Becomes a Law: The Civil Rights Act of I960 (I962); In Congress Assembled: The Legislativi Process in the National Governaent (to be published). Congressional Fellow of the American Political Science Association, I959-60. Contributor to legal and political science periodicals.

+A.B. I96r, Bradley University; A.M. 1963, The American University. Graduate student, School of Government and Public Administration, The American University. Fellow, National Defense Education Act.

${ }^{1} 48$ Stat. 670 (I934), 7 U.S.C. $\$ 608$ (1958).

- Staff of Hodse Comar. on Agriculture, 87th Cong., 2d Sess., History and Operations of thr U.S. Stgar PrograM I-2, 2I-22 (Comm. Print I962) [hereinafter cited as History and Operations].

Id. at 23,25 .

- General Sugar Quota Regulations, Ser. 4, No. r, Dec. 12, 1936. 
sanction to this arrangement, and assigned to countries that enjoyed the preferred status a total of 1.36 per cent of the foreign quota. ${ }^{5}$ In r95 I this figure was raised to four per cent. ${ }^{\circ}$ The countries that gained the most from this revision were the Dominican Republic, El Salvador, Haiti, Mexico, Nicaragua, and Peru.

In 1956 , Congress provided a more specific legislative basis for the allocation of sugar quotas, when it wrote extensive directions into the text of the statute. ${ }^{7}$ For the first time, the law itself contained an estimate of the nation's sugar needs. Although the Secretary of Agriculture would continue to make more current estimates, the congressional figure would provide the basis for minimum quotas on which foreign suppliers might depend. The quota that Congress incorporated into the law was to be apportioned on a percentage basis among domestic and foreign producers. An allocation formula for market growth above the basic quota was also provided. According to the formula, Cuba and the Philippines-which were the major foreign sources of sugar-would have a steadily decreasing share of the sugar that the United States might need in excess of the basic congressional figure. ${ }^{8}$

The 1956 legislation was due to expire on December 3 , I960. Before that date, however, an entirely new situation had arisen to inspire a number of foreign countries with visions of new profits to be made in the United States sugar market. Strained relations between the United States and revolutionary Cuba prompted President Eisenhower in 1960 to request authority to cut or even withhold entirely the Cuban quota. ${ }^{9}$ Congress granted the presidential request, devised a formula for the reallocation of the Cuban quota, and extended the basic sugar legislation for three months. ${ }^{10}$ On July 7, I960, Eisenhower made use of his authority to cancel the remaining portion of Cuba's 1960 quota. ${ }^{11}$

According to the formula that was promulgated by Congress in Ig60, the Dominican Republic was to receive the largest share of the cancelled Cuban quota. It was at this time, however, that the Organization of American States voted for economic sanctions against the Trujillo regime in the Dominican Republic. ${ }^{12}$ Although President Eisenhower promptly requested statutory authority to withhold the Dominican share of the Cuban reallocation, ${ }^{13}$ Congress adjourned without taking action on the request. ${ }^{14}$ To compensate for this legislative inaction, the Administration levied a special import fee on the reallocated sugar. ${ }^{15}$ The result was that the

"6r Stat. 922 (I947), 7 U.S.C. \$ I I0I et seq. (I958).

${ }^{\circ} 65$ Stat. 3 I 8 (I95I), 7 U.S.C. \$III2 (1958).

7o Stat. 217 (1956), 7 U.S.C. \$ III2 (I958).

The share provided by the other countries would rise from $1.8 \%$ in 1956 to $15.41 \%$ in 1957 .

D.Y. Times, March 77 , I960, p. 14, col. 4 .

${ }^{10} 74$ Stat. 330 (1960), 7 U.S.C.A. $\$ 1158$ (Supp. I963).

1125 Fed. Reg. 6414 (1960).

${ }^{12}$ N.Y. Times, Aug. 21, Ig6o, p. I, col. 5.

${ }^{18}$ Id., Aug. 24, r960, p. r, col. 2.

14 For an interpretation of the role of Harold Cooley (D., N.C.), Chairman of the House Agriculture Committee, in the maneuvering over the Dominican quota, see Visions of Sugar Plums, The Reporter, July 19, I962, p. 16.

${ }_{15} 25$ Fed. Reg. 9198 (1960). 
premium on this Dominican sugar was effectively eliminated.

In I96r, Congress extended the sugar legislation to June 30, 1962, and directed the President to give consideration "to countries of the Western Hemisphere and to those countries purchasing United States agricultural commodities" when reallocating the Cuban quota. ${ }^{16}$ The Department of Agriculture, in administering this Act, gave temporary reallocations of the Cuban quota to a number of countries that had no permanent quota status. Other countries received reallocations in excess of their existing quotas. ${ }^{17}$

Foreign sugar interests were hopeful that the foundation had been laid for securing a permanent or increased quota, as the case might be, in the new sugar legislation that Congress was expected to enact in $1962 .^{18}$ There was a general expectation that Congress would make cuts in the Cuban reserve quota in Ig62, and thus pave the way for the indefinite entrenchment of new foreign sugar interests in the American market.

The Kennedy Administration, however, had come to the conclusion that the situation was getting out of control. Its position was explained in some detail in an address by Lawrence Myers, director of the Sugar Division of the Commodity Stabilization Service in the Department of Agriculture.10 Myers focused attention on the shortcomings of the country quota system, emphasizing that the exclusion of Cuba meant that there could no longer be complete assurance of stability in either the supply or the price of sugar. He also pointed out that the premium allowed to quota areas was in actuality an exceedingly inefficient form of foreign aid. ${ }^{20}$ Myers called for a global quota that would allow foreign interests to bid competitively for the United States market and enable Cuba to regain her place in this market when normal relations were re-established.

But the Administration was in a weak position to achieve the goals that Myers had described. There was almost no support, even within the Executive Branch itself, for abolition of the country quota system. Only the State Department backed

${ }^{10}$ The act also gave the President authority to withhold the Dominican share of the reallocation. 75 Stat. 40 ( $\mathrm{I} 96 \mathrm{I}$ ), 7 U.S.C.A. $\S \mathrm{II} 58$ (Supp. I963). The Dominican Republic received a portion of the Cuban quota when diplomatic relations with the United States were re-established after the overthrow of the Trujillo government.

${ }^{17}$ Countries receiving new quotas were: Australia, Brazil, the countries of the British West Indies (although British Guana had had a small quota), Colombia, Ecuador, El Salvador, Fiji Islands, French West Indies, Guatemala, India, and Ireland. U.S. Foreign Agriculture Service, Dep't op Agriculture, New Sughr Legistation Increases Foreign Sources of Supply, Foreign Agriculture Cincular, Sugar FS $4-62$, at 3 (I962) [hercinafter cited as New Sugar LegisLation].

${ }^{1 s}$ Interview with Arthur L. Quinn, representative for the British West Indies Sugar Association, on January $24,1963$.

19 "A Sugar Import Fee," an address to the Sugar Club, New York City, February 15, 1962, published in U.S. Agricultural Stabilization and Conservation Service, Sugar Division, Dep't of Agriculturr, Sugar Reports, No. in8, at 6-15 (1962).

${ }^{20}$ Myers might have been referring to the fact that the money represented by the premiums often trickles haphazardly into a country's economy after reaching the hands of the large sugar interests. See the comments of Senator Paul Douglas (D., IIl.) in I08 CoNG. Rec. Ir602 (daily ed. July 2, I962). 
the Administration position without reservation, and the White House was more concerned with the bills on agriculture and trade expansion. ${ }^{21}$ Industrial users of sugar, who have to pay the higher prices engendered by the quota system, were relatively passive, for none of them gain a competitive advantage under the system and almost all are in a position to shift the added cost to the consumer. ${ }^{22}$

Foreign sugar interests could see that the vacuum resulting from the existence of the vacant Cuban quota and the lack of support for the Administration's position had created a golden opportunity for them to improve their position in the United States sugar market. Accordingly, they were willing to spend considerable sums of money to achieve results at this opportune moment by means of intensive lobbying efforts. The lobbyists who represented them did not fail them. The extraordinary success of their campaign makes it important to investigate the methods they employed.

\section{The Lobbyists}

During the hearings held by the Senate Finance Committee on the Ig62 sugar bill, Senator J. William Fulbright (D., Ark.) expressed displeasure with the fact that foreign interests generally followed the practice of hiring Americans to argue their case for sugar quotas. ${ }^{23}$ Fulbright, who is chairman of the Senate Foreign Relations Committee, said he felt that it would be far preferable for such presentations to be made by official diplomatic representatives-such as commercial attachés—of the countries concerned. Evidently, however, foreign governments believe that such a procedure would not be preferable from their point of view. For one thing, the Government of the United States is a highly complex entity, and even a knowledgeable foreigner might find it exceedingly difficult to pinpoint the critical spots in which pressure might influence decisions. In addition, there is a feeling that the Government is more receptive to American citizens than to foreign nationals. Especially when the stakes are high, foreign interests appear convinced that they are wise to employ United States citizens to promote their cause.

But an American who acts as a foreign lobbyist finds himself at a serious disadvantage compared with the lobbyist who represents domestic interests. The domestic lobbyist has power behind him, for in the final analysis he represents votes. As a consequence, congressmen will tend to treat him with respect, even if the legislation for which he is campaigning is illogical in terms of the national interest. In contrast, the lobbyist for a foreign nation can exercise no such "legitimate"

\footnotetext{
${ }^{21}$ For a comment on the lack of Administration enthusiasm, see N.Y. Times, July 8, $1962, \S 4, \mathrm{p} .5$, col. I (weather ed.).

${ }^{22}$ Interview with Lawrence Myers, Director, Sugar Division; Department of Agriculture, January 22, 1963.

${ }^{28}$ Hearings Before the Senate Commitee on Finance on H.R. 12154, Sugar Act Amendments of 1962, 87th Cong., 2d Sess. 357-58 (1962) [hereinafter cited as Sugar Act Amendments]. For a sympathetic approach to the Fulbright idea, see The Lobby Network, The New Republic, July 16, 1962, p. 7 .
} 
pressure, for he commands the votes of no American citizens. Unless he can prove that what his principal wants would be in the national interest of the United States, there is no political reason why congressmen should listen to him.

It is thus understandable that the agents of foreign governments are tempted to resort to unconventional methods of lobbying. But it is impossible to learn from the reports which they are legally required to file ${ }^{24}$ exactly how they use to the best advantage the abundant resources that are made available to them. The reports, as a mater of fact, tend to raise questions, rather than to provide answers.

The case of a lobbyist named I. Irving Davidson is fairly typical. From r955 through 1959 , Davidson was employed by President Luis Somoza of Nicaragua. His receipts from this source were only $\$ 6,000$ in 1955 , and rose to a still comparatively modest $\$ 22,000$ in 1956 . The following year, they remained at this same level. But in I958, they jumped to $\$ 374,035$, only to drop back to $\$ 89,090$ in $1959 .^{25}$ The records are vague as to how the extraordinary sum of $\$ 374,035$ was spent in $195^{8}$, and why that year was so special in the lives of I. Irving Davidson and Luis Somoza. An examination of the foreign agent registration files of the Department of Justice provides only the most general explanation of how the large increase was spent. Although the registration form provides spaces for facts about the date, amount, purpose, and recipient of each expenditure, these headings were ignored by Davidson in favor of a general statement in narrative form. ${ }^{26}$

Some foreign principals attempt to provide incentive for their lobbyists in the form of contingency agreements. ${ }^{27}$ The typical such contract calls for payment of a base fee to the lobbyist, with additional sums hinging upon the size of the quota that the principal is awarded. But if the contingent fee helps to spur a lobbyist to work hard, it also may invite him to work unscrupulously. President Kennedy was clearly engaging in understatement when he told a press conference that "it's an unfortunate situation where men are paid large fees by foreign governments to secure quotas and where, in some cases, there are contingency fees. . . . that is not satisfactory."28

The payment of contingent fees is only one of the methods employed by foreign governments to make up for the fact that they cannot exert normal political pressures. Another is the tendency to retain lobbyists with political influence to sell. Thus, many

24 52 Stat. 631 (1938); 53 Stat. 1244 (1939); 56 Stat. 248 (I942).

${ }^{25}$ ro7 Cong. Rrc. Iroro (196r).

${ }^{20}$ See file on I. Irving Davidson, Registration No. 886, Supplemental Registration Statement for SixMonth Period Ending October 18, 1958, answer $9(\mathrm{c})$.

${ }^{37}$ Oscar Chapman (Mexico), James W. Riddell (India), Albert S. Nemir (Brazil), and Ernest Schein (Colombia) worked on such a basis in 1962 . For a table showing how much more the House bill was worth to them than the Administration bill, see ro8 CoNG. Rec. I1045 (daily ed. June 27, 1962). For details concerning their contracts, see Staff of Senate Comm. on Finance, 87th Cong., 2d Sess., Compendium of Statements SubMitted by Representatives of Domestic and Foreign Sugar Producers and Other Representatives Who Expressed Interest in the Sugar Act AMendments op I962 (H.R. I2154) $8,15,30-31,35-36$ (Comm. Print I962) [hereinafter cited as Compendium].

${ }_{28}$ N.Y. Times, July 6 , x 962, p. 8 , col. 3 (city ed.). 
of the lobbyists hired by foreign sugar interests are men who have held important government jobs or positions of influence.

In the lobbying over the $195^{6}$ extension to the Sugar Act, for instance, two Cuban sugar associations were represented by the firm of Cleary, Gottlieb, Steen, and Ball. ${ }^{29}$ George W. Ball, a partner in the firm, was to become Under Secretary of State in the Kennedy Administration. Examples of influential sugar lobbyists who were interested in the 1962 legislation include the following:

r. Oscar L. Chapman, a representative of Mexican sugar interests, who was President Truman's Secretary of the Interior. ${ }^{30}$

2. Robert L. Farrington, retained by Republic of China interests, who is former general counsel of the Department of Agriculture.

3. Ganson Purcell, in the employ of Nicaraguan sugar interests, who was chairman of the Securities and Exchange Commission under Presidents Roosevelt and Truman.

4. Charles H. Brown, a representative of the Fiji Islands, who was, from r957 to I96r, a Democratic congressman from Missouri. ${ }^{31}$ (Taking advantage of this fact, Brown began his statement to the House Agriculture Committee with an expression of appreciation for "this opportunity to be back in this room with this very fine committee. I tried to serve on this committee for 4 years while I was here ....") ${ }^{32}$

5. James H. Rowe, Jr., retained by Haitian interests, who is a former administrative assistant to President Franklin D. Roosevelt, assistant attorney general (I94II943), and counsel to the Senate Majority Policy Committee (1956).

6. Rocco Siciliano, representing El Salvador sugar interests, who is a former assistant secretary of labor (I953-1957) and special assistant to the President for personnel management (I957-r959). ${ }^{33}$

7. Ernest Schein, the lobbyist for Colombian sugar interests, who is chairman of the District of Columbia Board of Elections. ${ }^{34}$

8. Walter Sterling Surrey, hired by sugar interests of the Dominican Republic and of the French West Indies, who is a former consultant to the State Department and to the Economic Cooperation Administration. (Another Dominican representative, Philip F. Maguire, was formerly a special assistant to President Truman.) ${ }^{35}$

9. Sheldon Z. Kaplan, on the payroll of Guatemalan interests, who is a former staff member of the House Foreign Affairs Committee ${ }^{36}$ and a former legal assistant

29 The National Cuban Sugar Mill Owners Association and the Cuban Sugar Cane Growers Association. Io7 Cong. Rec. I Ioog (196r). During this period, the firm earned $\$ 87,000$ in fees. N.Y. Times, Feb. 5, $x 963$, p. $x$, col. 3 (western ed.). In 1962 the firm (now Cleary, Gottlieb, and Steen) represented, inter alia, Australian sugar interests. Compendium, op. cit. supra note 27 , at 7 .

${ }^{80}$ ro8 Cong. Rec. Ir609 (daily ed. July 2, 1962).

"sugar Lobby Reports, 20 CONG. Q. WEekLy REPORT xI73-74 (week ending July I3, I962).

${ }^{32}$ Hearings on H.R. 11730, Sugar, Before the House Committee on Agriculture, 87th Cong., 2d Sess. 443 (Ig62) [hereinafter cited as Sugar].

${ }^{38}$ Sugar Lobby Reports, supra note 3I, at II74.

- U.S. Congresstonal Directory 638 (1962).

${ }^{38}$ Sugar Lobby Reports, supra note 31, at 1174 .

${ }^{20}$ Washington Post, July 5, 1962, p. A4, col. 1. 
to Senator Thomas A. Dodd (D., Conn.), (himself at one time a representative of Guatemalan interests). ${ }^{37}$

ro. James W. Riddell, employed by sugar interests in India, who at one time served on the staff of the House Ways and Means Committee. ${ }^{38}$

A number of the lobbyists have an extremely important commodity to sell: friendship with Congressman Harold D. Cooley (D., N.C.), chairman of the House Agriculture Committee. ${ }^{39}$ Without doubt, Cooley is the key to sugar legislation. His power is the result of a combination of constitutional and parliamentary factors in his favor.

The constitutional source of Cooley's power is the fact that sugar legislation, since it involves taxation, must originate in the House. ${ }^{40}$ This requirement makes it possible for Cooley, as chairman of the committee in charge, to delay proposed sugar legislation until late in a congressional session or until shortly before the scheduled expiration of existing legislation. ${ }^{41}$ Pressure of time is then usually sufficient to force the Cooley measure through the Senate, without significant alteration. For example, it was not until June 19 , 1962 , that the House passed a sugar bill to replace legislation due to expire only eleven days later, when the fiscal year would end.

Like the constitutional factor, parliamentary rules and customs contribute to Cooley's power over sugar. Although he may be a weak chairman when his committee is considering legislation on other commodities, ${ }^{42}$ Cooley is indisputably in charge when it comes to sugar legislation. Unlike bills on all other commodities, sugar legislation is screened not by a subcommittee but by the full Agriculture Committee. ${ }^{43}$ This procedure, of course, enhances Cooley's power over sugar, since he is chairman of the parent committee. Members of the committee are extremely unwilling to risk incurring his wrath, because he may take revenge regarding other legislation in which they are interested. In 1962 , it happened that Congress was considering a controversial Administration farm bill, for which Cooley's support was direly needed. Thus, while Administration supporters on the committee were dis-

${ }^{37}$ In spite of Dodd's former connections, he was almost put in charge of a projected "investigation" by the Senate Judiciary Committee into sugar lobbying. The planned inquiry was cancelled after the New York Times gave front-page treatment to an article that included this paragraph: "Heading the Judiciary group will be Senator Thomas J. Dodd, Democrat of Connecticut, who in 1957 and 1958 was a registered foreign agent for the government of Guatemala. He received a total of $\$ 66,666.58$ in fees, according to statements he filed with the Department of Justice." N.Y. Times, July 7, 1962, p. $x$, col. 1 (city ed.). See also N.Y. Times, July 9, I962, p. I, col. 3.

${ }^{38}$ Washington Post, July 5, 1962, p. A4, col. I.

${ }^{30}$ See N.Y. Times, July 3, 1962, p. 1, col. 3 and id. July 4, 1962, p. 1, col. 2.

${ }^{40}$ U.S. ConsT., art. I, $\$ 7$.

${ }^{31}$ Cater \& Pincus, Our Sugar Diplomacy, The Reporter, April 13, 196r, p. 27. Walter Pincus is now directing the investigation by the Senate Foreign Relations Committee into foreign lobbying activitics.

${ }^{12}$ See Jones, Representation in Congress: The Case of the House Agriculture Committee, 55 Ass. Pot. Scr. Rev. 359 (196r).

${ }^{43}$ See also id. at $36 \mathrm{r}$; Sugar, supra note 32 , at $\mathrm{x}$. 
gruntled with the chairman's handling of the sugar bill, they were unwilling to provoke him at that particular time.

Since Cooley and the House Agriculture Committee constitute the most important single influence on sugar legislation, it is little wonder that foreign governments with an interest in sugar try to cultivate both the chairman and the members of the committee. In 1955, for instance, the Trujillo regime offered the committee an expenses-paid trip to the Dominican Republic-only two months before the committee was scheduled to open hearings on the extension of sugar legislation.4 Cooley and his wife chose not to make the trip, but his son, daughter-in-law, and sister (who was clerk of the committee) accepted the invitation. ${ }^{45}$ Apparently several members of the committee did, too, for a New York Times reporter found in the Dominican archives a letter from Committee Vice Chairman W. R. Poage (D., Tex.), thanking Trujillo for the "outstanding hospitality" shown to the committee. $^{48}$ Cooley, himself, does not feel that it was improper for the Dominican Republic to pay the committee's traveling expenses. ${ }^{47}$ The author of the following limerick might be expected to disagree:

There was a young lady from Kent

Who said that she knew what it meant

When men took her to dine,

Gave her cocktails and wine,

She knew what it meant-but she went. ${ }^{48}$

\section{II}

\section{The Sugar Act Amendments}

On May 14, I962, the Administration submitted to Congress its bill to deal with the sugar problem. ${ }^{40}$ The legislation proposed, in effect, the elimination of the country quota system after an interval of five years. During the transitional period, gradually increasing import fees would be imposed on quota sugar. These fees would dispel the advantage of selling sugar in the artificially high American market. At the end of five years, the fees would be so high that they would entirely wipe out the difference between the premium domestic price and the lower world market price.

The Agriculture Committee heard testimony on the Administration bill from a parade of witnesses, including numerous representatives of foreign sugar interests. The foreign lobbyists, of course, opposed the bill. But they went much farther and

“N.Y. Times, July 3, x962, p. 5, col. x.

${ }^{10}$ Cater \& Pincus, stupra note $4 \mathrm{I}$.

${ }^{10}$ N.Y. Times, July 3, I962, p. 5, col. I.

${ }^{\prime 7}$ Cater \& Pincus, stepra note $4 \mathrm{I}$.

${ }^{48}$ Don K. Price, Government and Science 96 (1954).

$1^{\circ}$ H.R. II730 (a bill to amend and extend the provisions of the Sugar Act of 1948, as amended), 87th Cong., 2d Sess. (I962). 
urged the committee to increase already existing quotas and establish new ones as well. When the committee reported out a bill on June $15,1962,{ }^{50}$ the foreign lobbyists could not have been happier. All but one had succeeded in persuading the committee of the justice of their cause. ${ }^{51}$

The committee bill retained the full quota premium, greatly enlarged the quotas of most of the countries that were already benefiting from the system, and gave quotas to fifteen new areas. ${ }^{52}$ The bill also provided a formula for temporarily allocating the remainder of the Cuban reserve quota to specified areas. ${ }^{63}$

The House passed the committee bill on June 19 , Ig62, by a vote of 319-72.54 But when the legislation reached the Senate, it ran into serious trouble. At the very outset, lobbyists who testified before the Senate Finance Committee in support of the House bill were subjected to a searching interrogation. Openly hostile questions came from Senators Fulbright and Paul H. Douglas (D., Ill.). ${ }^{56}$ As chairman of the Foreign Relations Committee, Fulbright had already ordered a staff study of the activities of foreign lobbyists. ${ }^{56}$ It was not surprising, therefore, that the hearings occasionally sounded more like a lobbying investigation than like an inquiry into proposed sugar legislation.

Many of the lobbyists who had testified before the House Agriculture Committee did not bother to appear at the Senate hearings. At least one of them stayed away because he was confident that the House bill would not be appreciably changed. ${ }^{\mathbf{5 7}}$ Such optimists were in for a rude awakening, however. The bill reported out by the Senate Finance Committee on June 26, I962, was almost a carbon copy of the original Administration measure that the House had emasculated. The new quotas and reallocations added by the House were dropped, old quotas were reduced to levels not far from those proposed by the White House, and the drastic Administration position on import fees was accepted. ${ }^{68}$ The Senate promptly approved the committee bill..$^{59}$

Ultimate victory, however, was still to go to Cooley and the foreign lobbyists.

${ }^{50}$ House Comm. on Agriculture, Sugar Act Amendments of 1962, H. REp. No. 1829,87 th Cong., 2 d Sess. (1962).

si George Bronz, who represented the sugar interests of Ireland.

${ }^{2}$ Argentina, Australia, Brazil, British Honduras, British West Indies, Colombia, Ecuador, El Salvador, Fiji Islands, French West Indies, Guatemala, India, Mauritius, Paraguay, and South Africa. Nesu Sugar Legislation, supra note 17.

${ }^{58}$ As a bit of frosting, Chairman Cooley had inserted a provision that would have required the United States to repay to the Dominican Republic the fees this country had levied on the Dominican share of the Cuban reallocation during Trujillo's rule. N.Y. Times, July 3, 1962, p. 5, col. 1.

${ }^{34}$ ro 8 Cong. Rec. Ior 46 (daily ed. June 19 , 1962).

${ }^{85}$ Sugar Act Amendments, supra note 23, especially pp. 3I6-318, 352-358, 433.

${ }^{80}$ Staff of Senate Comm. on Foreign Relations, 87tr Cono., 2D Sess., Nondiplomatic Activities of Representatives of Foreign Governments at v (Comm. Print. I962) [hereinafter cited as NonDipLOMatTC ACTTITIEs].

${ }^{57}$ Quinn, interview, supra note 18.

${ }^{88}$ Senate Comm. on Finance, Sugar Act Amendments of 1962, SEN. Rep. No. 163I, 87th Cong., 2d Sess. (1962).

${ }^{80}$ The vote was 76-2. 108 Cong. Rec. 11064 (daily ed. June 27, 1962). 
The architects of their triumph were the members of the House-Senate conference committee that was appointed to reconcile the differences between the two bills. On almost every significant question, the Senate conferees surrendered. The reserve quota for Cuba that they accepted was a close approximation of the House's original figure; all new quotas proposed by the House, except those for Mauritius and Argentina, ${ }^{60}$ were retained; and existing quotas were raised much as the House had desired. Only one major substantive concession was made by the House. Approval was given to an import fee on quota sugar, beginning at ten per cent in 1962 and rising to thirty per cent in $1964^{61}$

Both the House and Senate gave overwhelming approval to the conference report, ${ }^{62}$ and on July 13, I962, the President signed into law the Sugar Act Amendments of $1962 .{ }^{63}$

\section{CoNCLUSION}

It is not easy to find rational justification for many of the quotas that were recommended by the House Agriculture Committee and included with little change in the final legislation. Countries like Australia, the Fiji Islands, India, Mauritius, ${ }^{64}$ and South Africa, to which new quotas were given, are all thousands of miles from the United States. In an emergency, none of them could supply sugar quickly, and they might not be able to furnish any at all in case of war. Furthermore, four of these countries-Australia, the Fiji Islands, Mauritius, and South Africa-may need an American subsidy less than some nations of the Western Hemisphere do, since these four already benefit from preferential trade arrangements with the United Kingdom. ${ }^{65}$ Nevertheless, each of them (as well as India) received a substantial permanent quota from the Agriculture Committee, and all but the Fiji Islands were given large temporary reallocations from the Cuban reserve quota. The permanent quotas of all but Mauritius survived, if in a slightly reduced form, in the final Act. $^{0 B}$

${ }^{\circ 0}$ Argentina was not completely left out, however, for after the enactment of the sugar bill, an amendment giving the President authority to distribute quotas of 375,000 tons of sugar was tacked onto an insignificant bill on the importation of honeybees. 76 Stat. I69 (I962), 7 U.S.C.A. 5 28I (Supp. 1963). President Kennedy, in a letter to Cooley, said that 20,000 tons of this would be assigned to Argentina. N.Y. Times, July 13, r962, p. 7, col. I.

${ }^{61}$ House Comm. on Conference Report, Sugar Act Amendments of 1962, H.R. ReP. No. 1957, 87th Cong., $2 d$ Sess. $(x g 62)$. The other concessions that were made to the Senate included the following: country quotas were to be extended to 1964 instead of to 1966 , as provided in the House bill; the reserve quota intended for Ireland was retained; and the specific formula for temporary reallocation of the remaining Cuban reserve quota was eliminated.

${ }^{\circ}$ House approval was by a vote of 248-31. I08 Cong. Rec. I1500 (daily ed. June 30, 1962). The Senate accepted the conference report, 54-12. I08 Cong. REc. Ir620 (daily ed. July 2, 1962).

os 76 Stat. 156 ( 1962$)$, 7 U.S.C.A. \$ IIII note (Supp. 1963).

ou Mauritus was dropped from the final bill in favor of the 10,000 -ton reserve that was intended for Ireland, a doubtful improvement. The whole maneuver caused Senator John J. Williams (R., Del.) to comment: "... A Apparently there are more Irish votes in Boston than there are Mauritians." I08 Covg. REc. II6II (daily ed. July 2, I962).

${ }^{85}$ Sugar Act Amendments, supra note 23, at 295, 494.

of Cooley's only explanation of these extra-hemispheric quotas was a statement that "... . we were told 
Other irrationalities in the 1962 Sugar Act were described by Fulbright on the Senate floor. The senator said that although current statistics showed Panama had only 5,000 tons available for export, the conference report gave it a quota of I5,000 tons; Guatemala received a 20,000-ton quota although it had been able to fill only about one-half of the lower quota it had held in rg6r. The quotas of Ecuador and Paraguay, too, were above their export capacity. ${ }^{67}$ (Another country that Fulbright might have mentioned was British Honduras, which received a new quota of ro,000 tons, although its representative admitted in the Senate hearings that it was having difficulty filling its sugar commitments to the United Kingdom.) ${ }^{08}$

Rather obviously, reason did not determine all the quotas awarded to these countries. The only explanation that remains is that lobbyists succeeded in diverting the attention of key congressmen from such mundane matters as meagre productive capacities and slow and undependable supply arrangements, and managed to turn their thoughts to other things.

The success that the foreign lobbyists enjoyed in 1962 may have serious results in the cases of some of their principals. In those countries that received quotas above their export capacities, considerable expansion of the sugar industry will probably be attempted. If Cuba ever returns to the United States sugar market and the quotas of these countries are abolished or even reduced, economic disaster may be the result. $^{69}$ Fulbright went on to declare that sugar interests in many of these countries, realizing the economic consequences of a Cuban-American rapprochement, now have a vested interest in keeping the two governments at swords' points. ${ }^{70}$ Thus the foreign sugar lobbyists were successful in promoting the enactment of legislation that may not only be detrimental to the interests of the United States, but that, in the long run, may be detrimental to the very countries whose sugar interests the lobbyists were representing.

It is possible that the lobbyists overreached themselves in 1962 and that the future will not be kind to them. Even before the Senate Foreign Relations Committee began its formal hearings into their activities, its staff produced a report pressing the Department of Justice to tighten up the enforcement of existing legislation affecting foreign agents. The report decried the failure of the Department to prosecute those who fail to comply fully with the legal requirement that they list their activities,

by the Director of the Sugar Branch that we could not rely safely upon the Western Hemisphere for adequate supplies of sugar at all times. ..." ro8 Cong. REc. Ir493 (daily ed. June 30, 1962).

67 ro8 Cong. Rec. II6I0-II6Ir (daily ed. July 2, I962).

${ }^{\circ}$ Sugar Act Amendments, supra note 23, at 358 . The lobbyist for British Honduras, L. Blaine Liljenquist, received no fee, but he had an interest in the sugar mill that would have been built if the country had been granted a 30,000-ton quota. I08 CoN. Rec. I1608 (daily ed. July 2, I962).

${ }^{\circ 8}$ See Fulbright's remarks, 108 Cong. REc. I 16 ro (daily ed. July 2, 1962).

${ }^{70}$ Sugar Act Amendments, supra note 23, at 239-40. The heads of the House Agriculture Committee gave little indication of any interest in the effect of sugar legislation on American foreign policy. At one point in the hearings, Vice Chairman Poage told a witness pointedly: "You are not talking to the Foreign Relations Committee; you are talking to the Agriculture Committec." Sugar, supra note 32, at $5 \mathrm{r} x$. 
expenses, and principals. ${ }^{71}$ The lack of prosecutions, according to the staff, did not necessarily reflect "full compliance with the law by the registrants. On the contrary, study of the foreign agent registration statements accepted as complete by the Justice Department and placed in their public files, discloses a number of apparent omissions and/or evasions."72

The Fulbright investigation will doubtless result in a more meticulous enforcement of existing laws regulating foreign lobbyists. Whether the senators on the Foreign Relations Committee will have the courage to dig deeply into the relationships that some of their own colleagues have maintained with the lobbyists is more doubtful. Equally speculative is the question of whether the Fulbright inquiry will lead to the passage of new legislation to remove some of the temptations that now exist for both foreign interests and the congressmen who control sugar legislation. Because the Constitution guarantees the right to petition government, there may be in the minds of some a presumption of constitutional invalidity regarding legislation to ban certain types of foreign lobbying. The authors, however, believe that no valid constitutional objection could be made against a narrowly drawn statute prohibiting lobbying for pay by an American on behalf of a foreign government. It hardly seems likely that this is the kind of petition that the framers of the first amendment intended to protect.

71 Nondiplomatic Activities, op. cit. supra note 56, at Io, 11 .

72 Id. at II. 


\section{The}

\section{DUKE LAW JOURNAL}

A law review edited by students of Duke University School of Law and devoted to a discussion of legal topics of current interest.

Volume 1963, No. 2 (Spring) Includes:

Articles:

Problem Child Among Labor Laws-The Walsh-Healey Act by Rudolf Modley, James R. Patton, Jr. and Gerard D. Reilly

Eunomics and Justice by Joseph Lazar

Nationalization of Foreign Owned Property and the Act of State Doctrine-Two Speeches by Martin Domke and Hans W. Baade

\section{Comment:}

State Reciprocity Statutes and the Inheritance Rights of Nonresident Aliens

Subscription Rate: $\$ 5.00$ per year (Four issues per year) Single Copy Prices

Volume I-VII $\$ 1.25$

Volume I959-Ig6r $\$ 1.50$

Volume $\mathrm{rg} 62-\mathrm{r} 963$ $\$ 2.00$

Address Subscriptions and Inquiries to The Managing Editor

DUKE LAW JOURNAL

DUKE UNIVERSITY School of LAW

Durham, N. C. 